\title{
Karyotype characterization and ZZ/ZW sex chromosome heteromorphism in two species of the catfish genus Ancistrus Kner, 1854 (Siluriformes: Loricariidae) from the Amazon basin
}

\author{
Renildo R. de Oliveira, Eliana Feldberg, Maeda B. dos Anjos and Jansen Zuanon
}

We present karyotypic characteristics and report on the occurrence of ZZ/ZW sex chromosomes in Ancistrus ranunculus (rio Xingu) and Ancistrus sp. "Piagaçu" (rio Purus), of the Brazilian Amazon. Ancistrus ranunculus has a modal number of $2 \mathrm{n}=48$ chromosomes, a fundamental number (FN) of 82 for both sexes, and the karyotypic formula was $20 \mathrm{~m}+8 \mathrm{sm}+6 \mathrm{st}+14 \mathrm{a}$ for males and $19 \mathrm{~m}+9 \mathrm{sm}+6 \mathrm{st}+14 \mathrm{a}$ for females. Ancistrus sp. "Piagaçu" presented $2 \mathrm{n}=52$ chromosomes, FN=78 for males and FN=79 for females. The karyotypic formula was $16 \mathrm{~m}+8 \mathrm{sm}+2 \mathrm{st}+26$ a for males and $16 \mathrm{~m}+9 \mathrm{sm}+2 \mathrm{st}+25 \mathrm{a}$ for females. The high number of acrocentric chromosomes in karyotype of Ancistrus sp. "Piagaçu" differs from the majority of Ancistrini genera studied so far, and may have resulted from pericentric inversions and translocations. The lower number of chromosomes in $A$. ranunculus indicates that centric fusions also occurred in the evolution of Ancistrus karyotypes. We conclude that karyotypic characteristics and the presence of sex chromosomes can constitute important cytotaxonomic markers to identify cryptic species of Ancistrus. However, sex chromosomes apparently arose independently within the genus and thus do not constitute a reliable character to analyze phylogenetic relations among Ancistrus species.

Nós apresentamos características cariotípicas e registramos a ocorrência de cromossomos sexuais ZZ/ZW em Ancistrus ranunculus (rio Xingu) e Ancistrus sp. "Piagaçu” (rio Purus), da Amazônia Brasileira. Ancistrus ranunculus teve um número modal de $2 \mathrm{n}=48$ cromossomos, um número fundamental (NF) de 82 para ambos os sexos, e a fórmula cariotípica $20 \mathrm{~m}+8 \mathrm{sm}+6 \mathrm{st}+14 \mathrm{a}$ para machos e $19 \mathrm{~m}+9 \mathrm{sm}+6 \mathrm{st}+14$ a para fêmeas. Ancistrus sp. "Piagaçu" apresentou $2 \mathrm{n}=52$ cromossomos, NF=78 para machos e $\mathrm{NF}=79$ para fêmeas. A fórmula cariotípica foi de $16 \mathrm{~m}+8 \mathrm{sm}+2 \mathrm{st}+26$ a para machos e $16 \mathrm{~m}+9 \mathrm{sm}+2 \mathrm{st}+25 \mathrm{a}$ para fêmeas. $\mathrm{O}$ alto número de cromossomos acrocêntricos no cariótipo de Ancistrus sp. "Piagaçu” difere da maioria dos gêneros de Ancistrini estudada até o momento, e pode ter resultado de inversões pericêntricas e translocações. O número mais baixo de cromossomos em $A$. ranunculus indica que fusões cêntricas também ocorreram na evolução dos cariótipos de Ancistrus. Nós concluímos que as características cariotípicas e a presença de cromossomos sexuais podem constituir marcadores citotaxonômicos importantes para identificar espécies crípticas de Ancistrus. Entretanto, cromossomos sexuais aparentemente surgiram de forma independente dentro do gênero e, deste modo, não constituem um caráter confiável para ser usado em análises de relações filogenéticas entre espécies de Ancistrus.

Key words: Hypostominae, Ancistrini, Cytogenetics, Evolution, Heterochromatin.

\section{Introduction}

Loricariidae is the largest family in the Siluriformes, with 683 valid species distributed across the entire Neotropical region (Isbrücker, 1980; Reis et al., 2003). The family is currently divided into six subfamilies: Delturinae, Hypoptopomatinae, Hypostominae, Lithogeneinae, Loricariinae, and Neoplecostominae (Reis et al., 2006). Within the Hypostominae, the tribe Ancistrini has been the subject of few taxonomic studies and its position within the subfamily is controversial (Isbrücker, 1980; Howes, 1983; Schaefer, 1987; Montoya-Burgos et al., 1998).

Ancistrini presently includes 217 valid species in 27 genera (Fish-Muller, 2003). Cytogenetic studies of this tribe, as well as of Loricariids overall, are scarce relative to the number of species involved. Only 23 species from seven genera (Ancistrus, Baryancistrus, Hemiancistrus, Megalancistrus, Panaque, Parancistrus, and Peckoltia) have been analyzed

Instituto Nacional de Pesquisas da Amazônia, Coordenação de Pesquisas em Biologia Aquática, Caixa Postal 478, 69011-970 Manaus, AM, Brazil. (RRO) deoliveirarr@hotmail.com; (EF) feldberg@inpa.gov.br; (MBA)maedaangel@hotmail.com; (JZ) zuanon@inpa.gov.br 
cytogenetically, most of then exhibiting the supposedly ancestral diploid number of $2 n=52$ chromosomes, predominantly meta- and submetacentrics (Artoni \& Bertollo, 2001; Souza, 2003; Souza et al., 2004; de Oliveira et al., 2006). Only species of the genus Ancistrus have shown diploid numbers that deviate from this condition, and the presence of a high number of acrocentric chromosomes, e.g. Ancistrus n. sp. (Alves et al., 2003), Ancistrus cf. dubius (Mariotto et al., 2004), Ancistrus n. sp.1 (Alves et al., 2006) and Ancistrus cf. dubius (Mariotto \& Miyazawa, 2006).

In Neotropical freshwater fishes, the most frequent morphologically differentiated sex chromosome system is ZZ/ ZW, making up 63\% (39 of 62) of described cases (Galetti et al., 1981; Haaf \& Schmid, 1984; Feldberg et al., 1987; Bertollo \& Cavallaro, 1992; Moreira-Filho et al., 1993; Centofante et al., 2002). Five occurrences of this type of sex chromosome system have been observed in the Loricariidae, of which two refer to species of Ancistrini: Ancistrus cf. dubius and Hemiancistrus spilomma (Andreata et al., 1993; Scavone \& Julio Jr., 1995; Artoni et al., 1998; Mariotto et al., 2004; de Oliveira et al., 2006).

Here we present the karyotypic structure and record the occurrence of ZZ/ZW sex chromosomes of two species of the genus Ancistrus and discuss possible mechanisms involved in the differentiation of this sex chromosomes.

\section{Material and Methods}

Ancistrus ranunculus Muller et al., 1994: five specimens (three males and two females) acquired from ornamental fish exporters (Turkys Aquarium, Manaus), from the rio Xingu, Altamira, Pará $\left(03^{\circ} 15^{\prime} 21^{\prime \prime S}, 52^{\circ} 12^{\prime} 45^{\prime \prime} \mathrm{W}\right)$ (Fig. 1a).

Ancistrus sp. "Piagaçu": seven specimens (three males and four females) collected in lago Aiapuá, on the left bank of the rio Purus, in the Piagaçu-Purus Sustainable Development Reserve $\left(04^{\circ} 27^{\prime} 26^{\prime \prime} \mathrm{S}, 62^{\circ} 11^{\prime} 56^{\prime \prime} \mathrm{W}\right)$. This apparently undescribed species (S. Fish-Muller, pers. comm.) presents the following color pattern: dorsal region dark grey with small white spots; ventral region yellowish grey with well-defined stipples, that in smaller specimens resemble ocelli; dorsal fin dark grey with pale stipples (Fig. 1b).

Voucher specimens were deposited in the fish collection at the Instituto Nacional de Pesquisa da Amazônia (INPA) (Ancistrus ranunculus: INPA 25624; Ancistrus sp. "Piagaçu": INPA25630).

Chromosomal preparations were obtained from kidney cells, following the "air-drying" technique of Bertollo et al. (1978). Approximately 30 metaphasic plates were analysed for each individual. The constitutive heterochromatin was identified according to Sumner (1972) and the nucleolar organizing regions (NORs) were detected using the technique

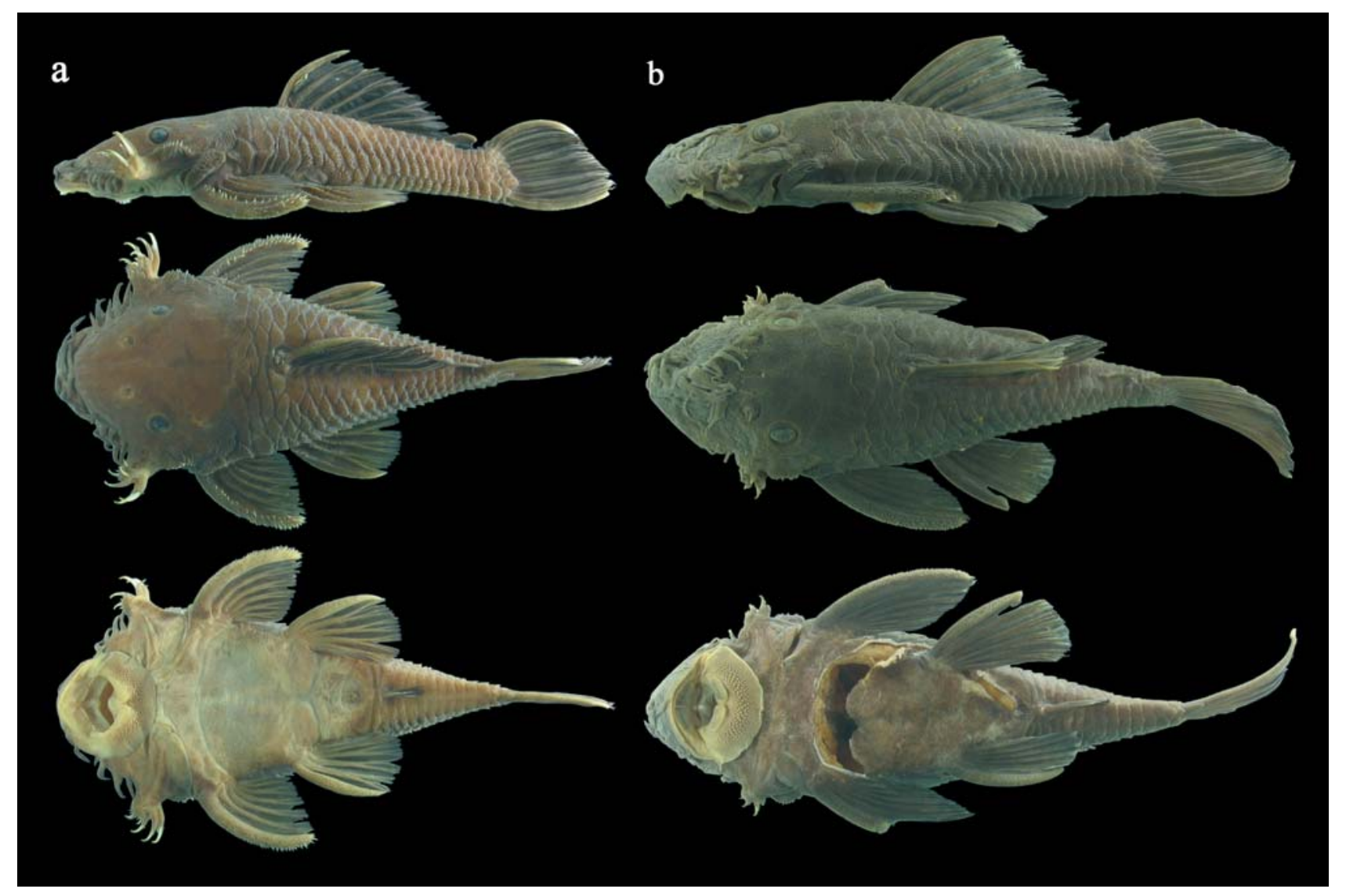

Fig. 1. Lateral, dorsal and ventral views of Ancistrus ranunculus, INPA 25624, $103 \mathrm{~mm}$ SL (a), and of Ancistrus sp. "Piagaçu", INPA25630, $128 \mathrm{~mm} \mathrm{SL}(\mathrm{b})$. 
described by Howell \& Black (1980). Chromosome morphology was based on arm ratios (long arm length divided by short arm length), as proposed by Levan et al. (1964). Chromosomes were classified as metacentric (m), submetacentric (sm), subtelocentric (st), or acrocentric (a). The fundamental number (FN) or arm number was determined by considering meta-, submeta- and subtelocentric chromosomes with two arms and acrocentrics with only one.

\section{Results}

Ancistrus ranunculus has a modal number of $2 \mathrm{n}=48$ chromosomes and a fundamental number of 82 for both sexes; however, the karyotypic formula was different for males $(20 m+8 s m+6 s t+14 a)$ and females $(19 m+9 s m+6 s t+14 a)$. Sex chromosomes of the type ZZ/ZW were found in this species, with the $\mathrm{Z}$ being a small metacentric, and the $\mathrm{W}$ a medium sized submetacentric. The NORs are located in the region proximal to the long arms of pair 16 . We also observed a size heteromorphism of the NORs between the homologues (Fig. 2).

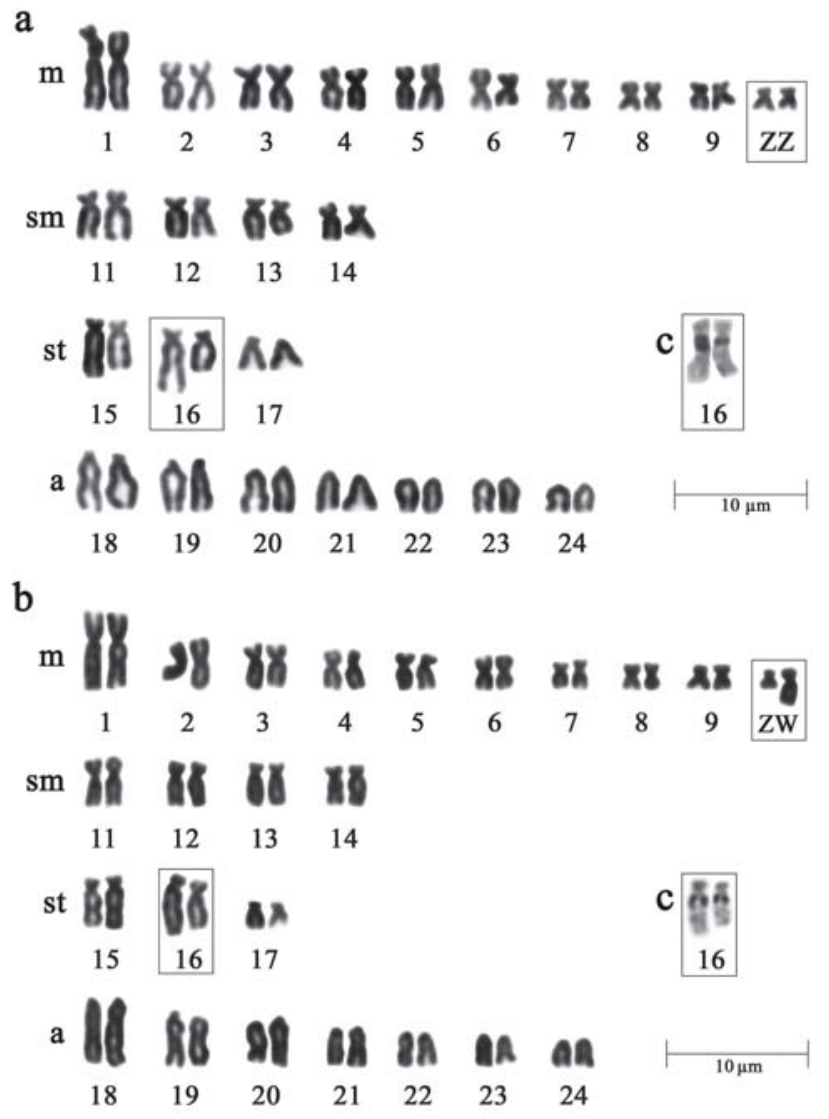

Fig. 2. Karyotypes of male (a) and female (b) Ancistrus ranunculus after conventional Giemsa-staining, evidencing the sex chromosomes (box) and the NOR-bearing chromosomes after silver-staining (c). $\mathrm{m}=$ metacentric; $\mathrm{sm}=$ submetacentric; $s t=$ subtelocentric; $a=$ acrocentric.
Ancistrus sp. "Piagaçu" has a modal number of $2 \mathrm{n}=52$ chromosomes and a fundamental number of 78 for males and 79 for females. The karyotypic formula is $16 \mathrm{~m}+8 \mathrm{sm}+2 \mathrm{st}+26 \mathrm{a}$ for males and $16 \mathrm{~m}+9 \mathrm{sm}+2 \mathrm{st}+25 \mathrm{a}$ for females. ZZ/ZW chromosomes were also found in this species, the $Z$ chromosome being a large acrocentric, and the $\mathrm{W}$ a small submetacentric. The NORs are found on the short arms of pair 26 (Fig. 3).

Ancistrus ranunculus has conspicuous blocks of heterochromatin in the distal region of pairs 18, 20,21, and 24; smaller blocks in the proximal region of pair 16; and a small pericentromeric block on pair 9. One of the chromosomes of pair 10 has, along with the small pericentromeric blocks observed in its homologue, a considerable portion of heterochromatin on the long arm in the female karyotype (Fig. 4a). In Ancistrus sp. "Piagaçu" we found small pericentromeric blocks on pairs $1,9,14,15,17,22,23,24$, and 25; interstitial blocks on the long arms of pairs 2 and 4 and on the short arm of pair 2; small distal blocks on the short arms of pair 1; and conspicuous distal blocks on the short arms of pair 26 (Fig. 4b). In this species, sex chromosomes did not exhibit heterochromatin blocks. In both species, the NORs were coincident with blocks of heterochromatin (Fig. 4).

\section{Discussion}

The Ancistrini has the supposedly ancestral diploid number of $2 n=52$ chromosomes, the majority of which are meta- and submetacentric (Artoni \& Bertollo, 2001; Alves et al., 2003). We found Ancistrus sp. "Piagaçu" to have the supposedly ancestral diploid number, yet its karyotype is composed of a high number of acrocentric chromosomes, a characteristic different from the majority of the Ancistrini species that have been studied so far. Pericentric inversions and translocations may be the principal rearrangements responsible for the differentiation of the karyotype in this species. The presence of $2 \mathrm{n}=48$ chromosomes in $A$. ranunculus corroborates the hypothesis of Alves et al. (2003), who suggest that centric fusions, like chromosome rearrangement, predominate in the evolution of Ancistrus karyotypes.

In a comparative karyotypic analysis of males and females, we found morphologically differentiated sex chromosomes of the type ZZ/ZW in both studied species. In A. ranunculus the $\mathrm{Z}$ chromosome is represented by a small metacentric (corresponding to one of the homologues of pair 10 of the complement), and the $\mathrm{W}$ chromosome by a medium sized submetacentric. In Ancistrus sp. "Piagaçu" the Z chromosome is a large acrocentric (pair 16) and the $\mathrm{W}$ is a small submetacentric.

The initial heterochromatization seems to be the principal factor in the differentiation of the majority of ZZ/ZW systems in fish, generally resulting in an increase in the size of the $\mathrm{W}$ chromosomes. Examples of this can be found in some species in the anostomid genus Leporinus (Galetti et al., 1981; Galetti \& Foresti, 1986; Galetti et al., 1995; Venere et al., 2004); in the prochilodontid Semaprochilodus taeniurus (Feldberg et al., 
1987) and in the Hypoptopomatinae loricariid Microlepidogaster leucofrenatus (Andreata et al., 1993); and in two species of the parodontid genus Parodon (Moreira-Filho et al., 1993; Centofante et al., 2002). However, past structural rearrangements seem to have occurred and many times are associated with repetitive sequences of DNA, as suggested for the differentiation of the W chromosome in species of the genus Triportheus (Artoni et al., 2001; Artoni \& Bertollo, 2002).

In the genus Ancistrus, the heterochromatization process is involved in the differentiation of the sex chromosome system of Ancistrus cf. dubius (Mariotto et al., 2004) and A. ranunculus (present study), however, the suggested pathway for these two differentiations seems to be distinct. In Ancistrus cf. dubius, there was an accumulation of heterochromatin over chromosome $\mathrm{Z}$, followed by the loss of this heterochromatin segment in W, in such a way that it appears much smaller and only possesses homology with the euchromatic segment of the $\mathrm{Z}$ chromosome. In $A$. ranunculus, the $\mathrm{W}$ chromosome is almost completely heterochromatic, with a considerable portion of heterochromatin on the long arm, while the $\mathrm{Z}$ chromosome is much smaller and has only a small block of heterochromatin in the centromeric position.

The differentiation of sex chromosomes may also be linked to structural rearrangements, resulting in the prevention of meiotic recombination (Beçak \& Beçak, 1969; Almeida-Toledo et al., 2000). Nevertheless, these events are more related to the emergence of multiple sex chromosome systems, as seen in the parodontid Apareiodon affinis (Moreira-Filho et al., 1980), in the sternopygid Eigenmania sp. (Almeida-Toledo et al., 1984), and in some populations of the erythrinid Hoplias malabaricus (Bertollo et al., 1997). While uncommon among species that have the simple ZZ/ZW mechanism, structural rearrangements seem to play an important role in the differentiation of sex chromosomes in the loricariids Loricariichthys platymetopon (Scavone \& Júlio Jr., 1995) and Hypostomus sp. (Artoni et al., 1998). For these species, it has been suggested that a pericentric inversion in an acrocentric chromosome similar to the $\mathrm{Z}$ chromosome, followed by a loss of chromosomic material, could have originated the $\mathrm{W}$ chromosome. We believe that a similar process has occurred in Ancistrus sp. "Piagaçu" since we did not find any heterochromatin blocks on the $\mathrm{Z}$ (large acrocentric) or $\mathrm{W}$ (small submetacentric) sex chromosomes.

The differentiation of sex chromosomes in Neotropical freshwater fish seems to have resulted from independent events, and its presence does not relate to species' phylogenetic relationships (Almeida-Toledo \& Foresti, 2001).

a
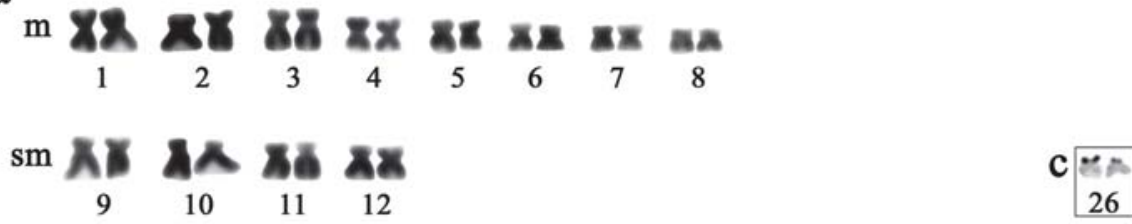

st

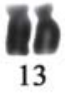

2

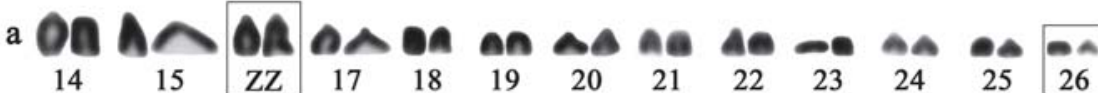

\begin{tabular}{ll|l|lllllllll|l}
14 & 15 & $\mathrm{ZZ}$ & 17 & 18 & 19 & 20 & 21 & 22 & 23 & 24 & 25 & 26
\end{tabular}

b
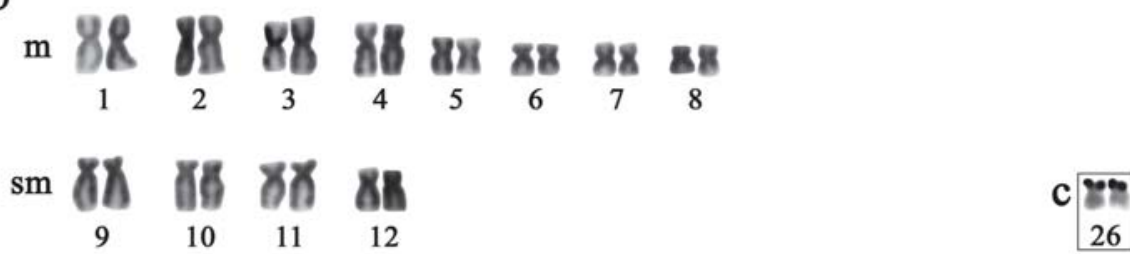

st

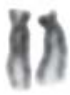

13

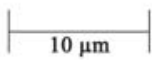

a 9 )
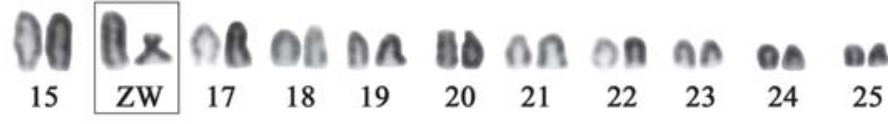

Fig. 3. Karyotypes of male (a) and female (b) Ancistrus sp. "Piagaçu" after conventional Giemsa-staining, evidencing the sex chromosomes (box) and the NOR-bearing chromosomes after silver-staining (c). $\mathrm{m}=$ metacentric; $\mathrm{sm}=$ submetacentric; $\mathrm{st}=$ subtelocentric; $\mathrm{a}=$ acrocentric. 


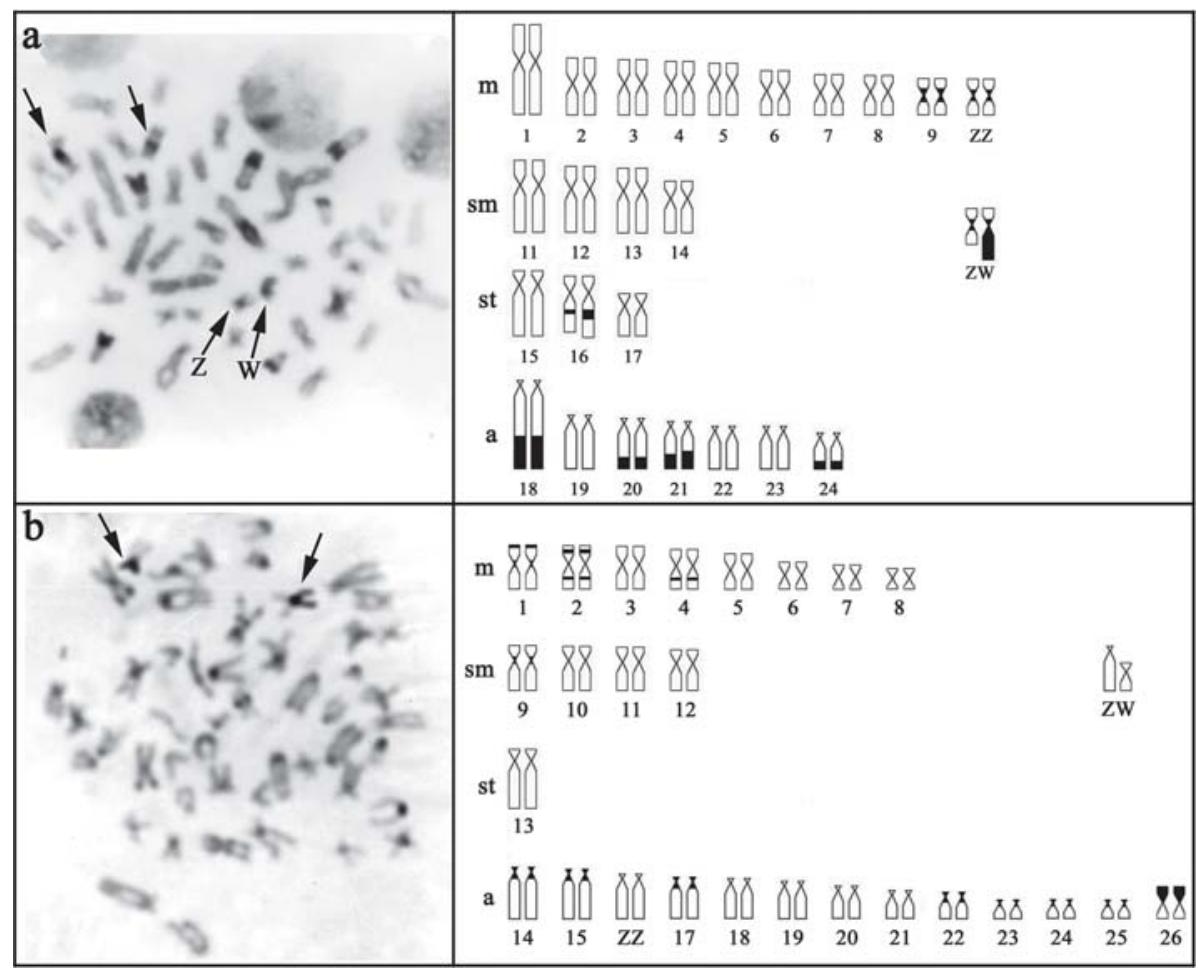

Fig. 4. Metaphase and idiogram showing the distribution of constitutive heterochromatin after C-banding technique in Ancistrus ranunculus (a) and in Ancistrus sp. "Piagaçu" (b). Arrows indicate the NOR-bearing chromosomes with positive Cbanding. $\mathrm{m}=$ metacentric; $\mathrm{sm}=$ submetacentric; $\mathrm{st}=$ subtelocentric; $\mathrm{a}=$ acrocentric.

Nevertheless, in Triportheus (Characidae) all species analyzed share a ZZ/ZW mechanism that may have originated in a common ancestor for this genus (Artoni et al., 2001; Artoni \& Bertollo, 2002). The occurrence of ZZ/ZW sex chromosomes in Ancistrus species probably do not represent a synapomorphy for the group, since they involve different chromosome pairs that vary in both size and morphology and probably resulted from distinct differentiation processes. Only A. ranunculus shows the most common mechanism observed among fish with ZZ/ZW sex chromosomes, characterized by an increase in the size of chromosome $\mathrm{W}$ through the accumulation of heterochromatin.

Ancistrus is a species-rich loricariid genus that seems to contain a large number of morphologically similar, undescribed species (S. Fish-Muller, pers. comm.). The results presented herein indicate that chromosome macrostructure, and especially the presence of sex chromosomes, represent important cytotaxonomic markers, which can help in the identification of cryptic species of that genus. However, sex chromosomes apparently arose independently within the genus and thus do not constitute a reliable character to analyze phylogenetic relations among Ancistrus species.

\section{Acknowledgements}

The authors are grateful to J. I. R. Porto for suggestions to this manuscript; to S. Fish-Muller, for the information about the identity of the species studied; and to INPA for logistical and financial support. This study was financed by the following agencies and projects: Brazilian National Research Council (CNPq, Process 130865 / 2004-4); by Institutional Research Project (PPI-INPA2-3750); PRONEX/FINEP (466098/ 2001-4); PNOPG/CNPq (550703/2001-2), Biological Dynamics of Forest Fragments Project (BDFFP - INPA / Smithsonian Institute); and by Fundação O Boticário de Proteção à Natureza (Process 0630-20042).

\section{Literature Cited}

Almeida-Toledo, L. F. \& F. Foresti. 2001. Morphologically differentiated sex chromosomes in neotropical freshwater fish. Genetica, 111: 91-100.

Almeida-Toledo, L. F., F. Foresti \& S. A. Toledo-Filho. 1984. Complex sex chromosome system in Eigenmannia sp. (Pisces, Gymnotiformes). Genetica, 64: 165-169.

Almeida-Toledo, L. F., M. F. Z. Daniel-Silva, C. E. Lopes \& S. A. Toledo-Filho, 2000. Sex chromosome evolution in fish. II. Second occurrence of a X1X2Y Sex chromosome system in Gymnotiformes. Chromosome Research, 8: 335-340.

Alves, A. L., C. Oliveira \& F. Foresti. 2003. Karyotype variability in eight species of the subfamilies Loricariinae and Ancistrinae (Teleostei, Siluriformes, Loricariidae). Caryologia, 56: 57-63.

Alves, A. L., C. Oliveira, M. Nirchio, A. Granado \& F. Foresti. 2006. Karyotypic relationships among the tribes of Hypostominae (Siluriformes: Loricariidae) with description of XO sex chromosome system in a Neotropical fish species. Genetica, 128: 1-9.

Andreata, A. A., L. F. Almeida-Toledo, C. Oliveira \& S. A. ToledoFilho. 1993. Chromosome studies in Hypoptopomatinae (Pisces, Siluriformes, Loricariidae). II. ZZ/ZW sex chromosome 
system, B chromosomes, and constitutive heterochromatin differentiation in Microlepidogaster leucofrenatus. Cytogenetics and Cell Genetics, 63: 215-220.

Artoni, R. F. \& L. A. C. Bertollo. 2001. Trends in the karyotype evolution of Loricariidae fish (Siluriformes). Hereditas, 134: 201-210.

Artoni, R. F. \& L. A. C. Bertollo. 2002. Evolutionary aspects of the $\mathrm{ZZ/ZW}$ sex chromosome system in the Characidae fish, genus Triportheus. A monophyletic state and NOR location on the W chromosome. Heredity, 89: 15-19.

Artoni, R. F., J. N. Falcão, O. Moreira-Filho \& L. A. C. Bertollo, 2001. An uncommon condition for a sex chromosome system in Characidae fish. Distribution and differentiation of $\mathrm{ZZ/ZW}$ system in Triportheus. Chromosome Research, 9: 449-456.

Artoni, R. F., P. C. Venere \& L. A. C. Bertollo. 1998. A heteromorphic ZZ/ZW sex chromosome system in fish, genus Hypostomus (Loricariidae). Cytologia, 63: 421-425.

Beçak, W. \& M. L. Beçak. 1969. Cytotaxonomy and chromosomal evolution in serpentes. Cytogenetics, 8: 247-262.

Bertollo, L. A. C. \& Z. I. Cavalaro. 1992. A highly differentiated $\mathrm{ZZ/ZW}$ sex chromosome system in a Characidae fish, Triportheus guentheri. Cytogenetics and Cell Genetics, 60: 6063.

Bertollo, L. A. C., M. S. Fontes, A. S. Fenocchio \& J. Cano. 1997. The X1X2Y sex system in the fish Hoplias malabaricus. I. G, C- and chromosome replication banding. Chromosome Research, 5: 493-499.

Bertollo, L. A. C., C. S. Takahashi \& O. Moreira-Filho. 1978. Cytotaxonomic considerations on Hoplias lacerdae (Pisces, Erythrinidae). Brazilian Journal of Genetics, 1: 103-120.

Centofante, L., L. A. C. Bertollo \& O. Moreira-Filho. 2002. A ZZ/ ZW sex chromosome system in a new species of the genus Parodon (Pisces, Parodontidae). Caryologia, 55: 139-150.

Feldberg, E., L. A. C. Bertollo, L. F. Almeida-Toledo, F. Foresti, O. Moreira-Filho \& A. F. Santos. 1987. Biological aspects of Amazonian fishes: IX. Cytogenetics studies in two species of the genus Semaprochilodus. Genome, 38: 1-4.

Fisch-Muller, S. 2003. Subfamily Ancistrinae (Armored catfishes). Pp. 373-400. In: Reis, R.E., S.O. Kullander \& C.J. Ferraris Jr. (Eds.). Check list of the Freshwater Fishes of South and Central America. Porto Alegre, Edipucrs, 729p.

Galetti Jr., P. M. \& F. Foresti. 1986. Evolution of the ZZ/ZW system in Leporinus (Pisces, Anostomidae) role of constitutive heterochromatin. Cytogenetics and Cell Genetics, 43: 43-46.

Galetti Jr., P. M., F. Foresti, L. A. C. Bertollo \& O. Moreira-filho. 1981. Heteromorphic sex chromosome in three species of the Leporinus (Pisces, Anostomidae). Cytogenetics and Cell Genetics, 49: 138-142.

Galetti Jr., P. M., N. R. W. Lima \& P. C. Venere. 1995. A monophyletic ZW sex chromosome system in Leporinus (Anostomidae, Characiformes). Cytologia, 60: 375-382.

Haaf, T. \& M. Schmid. 1984. An early stage of ZZ/ZW sex chromosomes differentiation in Poecilia sphenops var. melanistica (Poeciliidae, Cyprinodontiformes). Chromosoma, 89: 37-41.

Howell, W. M. \& D. A. Black. 1980. Controlled silver-staining of nucleolus organizer regions with a protective colloidal developer: as 1-step method. Experientia, 36: 1014-1015.

Howes, G. J. 1983. The cranial muscle of Loricarioid catfishes, their homologies and value as taxonomic characters (Teleostei: Siluroidei). Bulletin Britannic Museum History. (Zoology), 45: 309-345.

Isbrücker, I. J. H. 1980. Classification and Catalogue of the mailed Loricariidae (Pisces, Siluriformes). Verslagen en technische
Genevens, Universiteit van Amsterdam. 181p.

Levan, A., K. Fredga \& A. A. Sandberg. 1964. Nomenclature for centromeric position on chromosomes. Hereditas, 52: 201-220.

Mariotto, S., R. F. Artoni \& C. S. Miyazawa. 2004. Occurrence of sexual chromosome, of the type ZZ/ZW in Ancistrus cf. dubius (Loricariidae, Ancistrinae) of the Paraguay River Basin, Mato Grosso, Brazil. Caryologia, 57: 327-331.

Mariotto, S. \& C. S. Miyazawa. 2006. Ancistrus cf. dubius (Siluriformes, Ancistrinae), a complex of species. 1. Chromosomic characterization of four populations and occurrence of sexual chromosome of type XX/XY, in the Pantanal Basin of Mato Grosso, Brazil. Caryologia, 59: 299-304.

Montoya-Burgos, J. I., S. Fisch-Muller, C. Weber \& J. Pawlowski. 1998. Phylogenetic relationships of the Loricariidae (Siluriformes) basead on mitocondrial rDNA gene sequences. Pp. 279-330. In: Malabarba, L. R., R. E. Reis, R. P. Vari, Z. M. S. Lucena \& C. A. S. Lucena. (Eds.). Phylogeny and Classification of Neotropical Fishes. Porto Alegre, Edipucrs, 603p.

Moreira-Filho, O., L. A. C. Bertollo \& P. M. Galetti Jr. 1980. Evidences for a multiple sex chromosome system with female heterogamety in Apareiodon affinis (Pisces, Parodontidae). Caryologia, 33:83-91.

Moreira-Filho, O., L. A. C. Bertollo \& P. M. Galetti Jr. 1993. Distribution of sex chromosome mechanisms in Neotropical fish and description of a ZZ/ZW system in Parodon hilarii (Parodontidae). Caryologia, 46: 115-125.

de Oliveira, R. R., I. L. Souza \& P. C. Venere. 2006. Karyotype description of three species of Loricariidae (Siluriformes) and occurrence of the ZZ/ZW sexual system in Hemiancistrus spilomma Cardoso \& Lucinda, 2003. Neotropical Ichthyology, 4: 93-97.

Reis, R. E., S. O. Kullander \& C. J. Ferraris Jr. 2003. Check list of the Freshwater Fishes of South and Central America. Porto Alegre, Edipucrs, 729p.

Reis, R. E., E. H. L. Pereira \& J. W. Armbruster. 2006. Delturinae, a new loricariid catfish subfamily (Teleostei, Siluriformes), with revisions of Delturus and Hemipsilichthys. Zoological Journal of the Linnean Society, 147: 277-299.

Scavone, M. D. P. \& H. F. Júlio Jr. 1995. Cytogenetics analysis and heterochromatin distribution in ZZ/ZW sex chromosomes of the mailed catfish Loricariichthys platymetopon (Loricariidae, Siluriformes). Brazilian Journal of Genetics, 18: 31-35.

Schaefer, A. S. 1987. Osteology of Hypostomus plecostomus (Linnaeus), with a phylogenetic analysis of the Loricariid subfamilies (Pisces: Siluroidei). Contribution in Science, Natural History Museum of Los Angeles County, 394: 1-31.

Souza, A. C. P. 2003. Descrição cariotípica de peixes dos gêneros Baryancistrus, Parancistrus, Peckoltia e Ancistrus (Ancistrinae, Loricariidae) da Bacia Amazônica. Master thesis. Universidade Federal do Pará/ Museu Paraense Emílio Goeldi, Brazil. 130p.

Souza, A. C. P., A. L. Nascimento, J. R. Carvalho Jr ., R. M. S. Barros, E. Feldberg, C. Y. Nagamachi \& J. C. Pieczarka. 2004. Karyotypic analysis of Baryancistrus aff. niveatus (Ancistrinae, Loricariidae) by C-banding, Ag-Nor, CMA 3 , DAPI and FISH. Caryologia, 57: 219-223.

Sumner, A. T. 1972. A Simple technique for demonstrating centromeric heterocromatin. Experimental Cell Research, 75: 304-306.

Venere, P. C., I. A. Ferreira, C. Martins \& P. M. Galetti Jr. 2004. A novel ZZ/ZW sex chromosome system for the genus Leporinus (Pisces, Anostomidae, Characiformes). Genetica, 121: 75-80.

Submitted April 2007 Accepted June 2007 